\title{
ANALISIS KESULITAN BELAJAR DAN PENCAPAIAN HASIL BELAJAR SISWA MELALUI STRATEGI PEMBELAJARAN INKUIRI
}

\author{
Izaak. H. Wenno, Katerina Esomar, dan Venty Sopacua \\ Fakultas Keguruan dan Ilmu Pendidikan Universitas Pattimura \\ email:wennoiz@yahoo.co.id
}

\begin{abstract}
Abstrak: Tujuan penelitian ini adalah untuk mengetahui kesulitan belajar dan pencapaian hasil belajar siswa SMA pada materi elastisitas bahan. Penelitian ini merupakan penelitian deskritif dengan sampel kelas XI IPA 4 Negeri 5 Ambon. Data analisis kesulitan belajar diperoleh melalui angket, sedangkan data pencapaian hasil belajar diperoleh dari nilai formatif dan proses yang meliputi nilai kognitif, afektif, dan psikomotor. Data dianalisis dengan teknik statistik deskriptif. Hasil penelitian menunjukkan bahwa selama proses pembelajaran terdapat empat jenis kesulitan, yaitu kesulitan dalam menguasai konsep, mengaitkan hubungan antara konsep, menguasai rumus, dan mengoperasikan rumus saat menyelesaikan soal. Sebelum menggunakan strategi inkuiri, kemampuan siswa menguasai konsep antara $69,2-82,3 \%$. Setelah penggunaan strategi inkuiri, kemampuan siswa meningkat menjadi 90,8\%. Kemampuan mengaitkan antarkonsep meningkat menjadi 89,2\%. Kemampuan menguasai rumus $87,1 \%$, dan kemampuan mengoperasikan rumus untuk penyelesaian soal 91,3\%. Peningkatan hasil belajar juga terjadi pada konsep elastisitas bahan. Strategi pembelajaran inkuri dapat mengatasi kesulitan belajar siswa dan dapat mencapai hasil belajarnya pada materi elastisitas bahan.
\end{abstract}

\section{Kata Kunci: strategi pembelajaran inkuiri, kesulitan belajar, dan pencapaian hasil belajar}

\section{ANALYSIS OF STUDENTS' LEARNING DIFFICULTIES AND ACHIEVEMENT IN THE IMPLEMENTATION OF INQUIRY LEARNING}

\begin{abstract}
The purpose of this study is to revealstudents' learning difficulties and achievement in learning the concepts of material elasticityin class XI SMA. This research belongs to descriptive study done to a sample of class XI IPA4 Negeri 5 Ambon with the total of 39 students. Learning difficultiesdata were obtained through questionnaires before and after the implementation of inquiry learning, while achievement data were obtained from the formative and process values that includes cognitive (student worksheet), affective, and psychomotor aspects duringthe learning activities. The results show that during the process of learning physics in particular on the concept of material elasticity, there are four types of difficulties experienced by students, i.e. difficulty in mastering the concepts, difficulty in establishing links betweenconcepts, difficulty in mastering formulas, and difficulty in operating formulas for solving problems. The results showthat students' ability to master the concepts ranges 69.2 to $82.3 \%$ before applying the inquiry strategy and reaches $90.8 \%$ after using the strategy. The ability to link concepts increases to $89.2 \%$. The ability to master the formula reaches $87.1 \%$, and the ability to operate formulas for solving problemsis about $91.3 \%$. The learning outcomes are also improving. Thus, it can be concluded that inqury learning strategies can address students' learning difficulties and can help students achieve better results in learning material elasticity concept.
\end{abstract}

Keywords: inquiry learning strategies, learning difficult, and learning outcomes

\section{PENDAHULUAN}

Fisika merupakan salah satu mata pelajaran dari bidang Ilmu Pengetahuan Alam (IPA) atau sains yang diajarkan di sekolah menengah di Indonesia. Checkley (2010) mengemukakan bahwa fisika merupakan mata pelajaran yang penting dan patut dikuasai oeh pelajar pada era kemajuan teknologi dan informasi saat ini. Elwan (2013) menyatakan bahwa sebagai bagian dari sains, tujuan mata pelajaran fisika adalah untuk meningkatkan keterampilan proses sains, keterampilan observasi, kemampuan melakukan analisis, keterampilan berfikir tingkat tinggi, dan keterampilan berfikir kritis. Dengan demikian, 
penguasaan terhadap sains fisika merupakan sesuatu yang tidak dapat dihindari oleh siswa dalam proses pendididikan dan pembelajaran (Ukoh, 2012).

Derlina \& Afriani (2016) menyatakan bahwa kegiatan pembelajaran sains yang dilakukan sesuai dengan hakikat sains, akan memberikan makna pada proses pembelajaran sains itu sendiri. Dalam pembelajaran sains, siswa tidak hanya mempelajari sejumlah teori dan prinsip, tetapi juga harus menganalisis bagaimana cara memperoleh fakta dan prinsip tersebut. Pembelajaran sains juga harus mampu membuat siswa memiliki kemampuan untuk mengkonstruksi pengetahuannya sendiri, menggeneralisasikan dan mengaitkan konsep, menganalisis, dan menjawap pertanyaan.

Hasil pengamatan lapangan di SMA Negeri 5 Ambon menunjukkan bahwa siswa memiliki kesulitan dalam mempelajari fisika. Hal itu ditunjukkan dengan adanya perbedaan hasil belajar dan kemampuan di antara siswa. Hamalik (1990) menyatakan bahwa jika siswa mengalami kegagalan atau kemunduran dalam hasil belajar, hal itu berarti ada kesulitan yang dihadapi selama pembelajaran. Kesulitan belajar siswa juga dapat dideteksi dengan rendahnya hasil yang diperoleh atau hasil yang diperoleh tidak sesuai dengan yang diharapkan.

Kadangkala tidak semua kesulitan siswa dapat dipahami oleh guru. Padahal, dengan mengetahui kesulitan yang dihadapi oleh siswa dalam pembelajaran, guru dapat mencari solusi penanganan atau alternatif pemecahan masalah yang sesuai untuk mengatasi kesulitan yang dihadapi siswa dalam pembelajaran khususnya pembelajaran sains fisika. Selain itu, untuk mengatasi adanya kesulitan belajar siswa, maka guru dapat melakukan variasi penggunaan meode atau pendekatan mengajar sesuai denga topik yang diajarkan, dan yang dapat membangkitkan kemampuan analisis, dan keterampilan berpikir kritis siswa.

Salah satu strategi belajar yang digunakan dalam proses pembelajaran yang dapat mengaktifkan siswa untuk menemukan prinsip maupun konsep, yaitu strategi pembelajaran inkuiri (SPI). Trianto (2010) menyatakan bahwa inti dari pembelajaran kontekstual adalah inkuiri karena dengan inkuiri siswa akan memperoleh pengetahuan bukan hanya sebagai hasil dari mengingat seperangkat fakta-fakta, tetapi hasil dari menemukan sendiri. Hanafiah dkk (2009) menyatakan bahwa dalam pembelajaran berbasis inkuiri seluruh kemampuan peserta didik digali dan diberdayakan secara maksimal sehingga siswa dapat menemukan sendiri pengetahuan, sikap dan keterampilan sebagai wujud adanya perubahan prilaku.

Derlina \& Afriani (2016) menyatakan bahwa pengajaran berdasarkan inkuiri adalah suatu strategi yang berpusat pada siswa di mana dengan inkuiri siswa dibimbing untuk berada dalam suatu kondisi yang mengharuskan siswa mencari, dan menemukan jawaban-jawaban terhadap pertanyaan dalam proses oembelajaran mereka melalui suatu prosedur yang digariskan secara jelas dan terstruktur.

Rizal (2014) dan Derlina \& Afriani (2016) pembelajaran inkuiri memungkinkan siswa menjadi aktif dalam mencari pengetahuan sehingga akan meningkatkan makna dari apa yang mereka pelajari. Jika dilihat dari teori konstruktivistik yang dikembangkan oleh Piaget, bahwa pengetahuan itu akan bermakna manakala dicari dan ditemukan sendiri oleh siswa. Dalam hal ini siswa yang mengkonstruksi pemikirannya sendiri. Dilihat dalam pembelajaran inkuiri, guru hanya bersifat sebagai fasilitator ketimbang menjadi pengajar, sehingga dengan menggunakan strategi ini guru dapat mendorong siswa untuk mengembangkan skema yang terbentuk dalam pemikiran siswa dan menyediakan lingkungan belajar yang mendukung keaktifan siswa sehingga dapat meningkatkan hasil belajar siswa.

Penelitian mengenai penggunaan strategi inkuiri dalam pembelajaran fisika telah dilaporkan oleh banyak peneliti, di antaranya yaitu untuk mengatasi kesulitan belajar siswa dan meningkatkan hasil belajar siswa pada konsep cahaya (Wijayanti dkk, 2010), penguasaan konsep siswa (Rizal, 2014), meningkatkan hasil belajar fisika (Ngasarotur dkk, 2015), meningkatkan aktivitas belajar dan hasil belajar (Simatupang \& Tiramaida, 2015), serta memperbaiki dan meningkatkan keterampilan proses sains siswa (Derlina \& Afriani, 2016).

Tujuan penelitian ini adalah untuk mengetahui kesulitan-kesulitan belajar pada materi elastisitas bahan pada siswa kelas XI SMA Negeri 5 Ambon, dan untuk mengetahui dampak penggunaan strategi pembelajaran inkuiri terhadap peningkatkan hasil belajar siswa kelas XI SMA Negeri 5 Ambon. 


\section{METODE}

Penelitian ini menggunakan tipe penelitian deskritif kuantitatif dan kualitatif. Penelitian memfokuskan diri pada kesulitan belajar siswa pada materi elastisitas bahan dan hasil belajar siswa dengan menggunakan strategi pembelajaran inkuiri (SPI) kelas XI SMA Negeri 5 Ambon.

\section{$\begin{array}{lll}\mathrm{O}_{1} & \mathrm{X} & \mathrm{O}_{2}\end{array}$}

\section{Gambar 1. Rancangan Desain Penelitian}

Desain penelitian yang digunakan adalah one group pretest and posttest design. Dalam desain ini observasi dilakukan sebanyak dua kali yaitu sebelum eksperimen dan sesudah eksperimen. Observasi yang dilakukan sebelum eksperimen $\left(0_{1}\right)$ disebut pretes, dan observasi sesudah eksperimen $\left(\mathrm{O}_{2}\right)$ disebut postes.

Penelitian ini membawa siswa untuk mengetahui secara mandiri konsep atau prinsip dari materi elastisitas bahan dengan didukung oleh startegi pembelajaran inkuiri. startegi pembelajaran inkuiri adalah strategi pembelajaran yang melibatkan siswa secara aktif untuk mencari dan menemukan sendiri jawaban dari suatu permasalahan.

Untuk memperoleh data yang akurat dilakukan uji validitas (RPP, LKS, dan soal-soal tes hasil belajar) terlebih dahulu sebelum digunakan untuk mengambil data. Analisis data yang digunakan dalam penelitian ini adalah analisis data deskritif untuk kesulitan belajar siswa yang dilihat melalui angket kesulitan belajar siswa sebelum dan sesudah proses pembelajaran dengan menggunakan strategi pembelajaran inkuiri, dan pencapaian hasil belajar siswa dilihat berdasarkan nilai kognitif, afektif, psikomotor dan nilai formatif siswa. Persentase kesulitan belajar dihitung dengan menggunakan persamaan persentase (Sudjana, 1999).

\section{HASIL PENELITIAN}

Hasil analisis instrumen berupa angket tentang kesulitan belajar siswa pada materi elastisitas bahan menggambarkan kesulitan belajar yang dialami siswa pada materi elastisitas bahan sebelum menggunakan strategi pembelajaran inkuiri. Hasil yang dimaksud disajikan pada Tabel 1 .

Terdapat empat tipe kesulitan belajar yang dihadapi oleh siswa dalam mempelajari konsep elastisitas bahan. Kesulitan-kesulitan tersebut adalah kesulitan menguasai konsep, kesulitan mengaitkan hubungan antarkonsep, kesulitan menguasai rumus, dan kesulitan mengoperasikan rumus dalam menyelesaikan soal. Dari keempat kesulitan tersebut, persentase kesulitan yang paling tinggi adalah mengaitkan antarkonsep, sedangkan kesulitan menguasai konsep adalah yang terrendah.

Setelah penggunaan strategi inkuiri, kesulitan belajar siswa pada keempat tipe kesulitan belajar mengalami penurunan, sebaliknya semakin besar persentase siswa yang tidak mengalami kesulitan. Hasil tersebut disajikan pada Tabel 2.

Data Nilai Akhir siswa setelah pembelajaran didapat dari persamaan $N A=\frac{6 \mathrm{P}+4 \mathrm{~F}}{10}$.

Kualifikasi dan presentase siswa dalam mencapai NA (Nilai Akhir) disajikan pada Tabel 3.

Hasil akhir dari proses pembelajaran sainsfisika dapat dikategori baik, dengan rata-rata pencapaian sebesar 84,9.

\section{Pembahasan}

Analisis Kesulitan Belajar Siswa sebelum Penggunaan Strategi Pembelajaran Inkuiri

Martini (2014) mengemukakan bahwa ada beberapa kesulitan yang dimiliki oleh siswa, yaitu kesulitan dalam memahami materi yang diajarkan, kesulitan mengerjakan tugas, dan kesulitan dalam memahami isi buku teks. Dalam penelitian ini, peneliti menemukan empat jenis kesulitan yang dihadapi siswa dalam pelajaran fisika terutama pada materi elastisitas bahan yaitu kesulitan pe-

Tabel 1. Presentase Kesulitan Belajar Siswa pada Materi Elastisitas Bahan sebelum Menggunakan Strategi Pembelajaran Inkuiri

\begin{tabular}{|c|c|c|c|}
\hline Jenis Kesulitan Belajar & $\begin{array}{l}\text { Tidak } \\
\text { Sulit }\end{array}$ & $\begin{array}{c}\text { Cukup } \\
\text { Sulit }\end{array}$ & Sulit \\
\hline 1. Kesulitan menguasai konsep & $14,9 \%$ & $15,9 \%$ & $69,2 \%$ \\
\hline 2. Kesulitan mengaitkan hubungan antar konsep & $8,2 \%$ & $9,7 \%$ & $82,1 \%$ \\
\hline 3. Kesulitan menguasai rumus & $12,3 \%$ & $16,4 \%$ & $71,3 \%$ \\
\hline 4. Kesulitan mengoperasikan rumus dalam menyelesaikan soal & $7,2 \%$ & $13,8 \%$ & $79 \%$ \\
\hline
\end{tabular}


nguasaan konsep, kesulitan mengaitkan hubungan antar konsep, kesulitan memahami rumus, dan kesulitan menerapkan rumus untuk penyelesaian soal.

Kesulitan menguasai konsep (69,2\%) lebih tinggi jika dibandingkan dengan siswa yang tidak mengalami kesulitan menguasai konsep $(30,8 \%)$. Tingginya persentase siswa yang mengalami kesulitan menguasai konsep yang diajarkan menunjukkan bahwa pembelajaran fisika khususnya pada konsep elastisitas bahan, benar-benar tidak dipahami oleh siswa.

Kesulitan belajar siswa yang kedua adalah ketidakmampuan membuat kaitan (mengaitkan) antar konsep $(82,1 \%)$ dan sisanya $(17,9 \%)$ yang tidak memiliki kesulitan atau yang sudah memiliki kemampuan membuat hubungan antar konsep.

Hasil ini menunjukkan bahwa siswa semakin sulit dalam belajar khususnya terhadap konsep elastisitas bahan. Jika dikaitkan dengan kesulitan pertama yaitu kesulitan menguasai konsep, maka hasil ini menunjukkan suatu hubungan bahwa siswa yang tidak menguasai konsep juga akan mengalami kesulitan untuk mengaitkan antar konsep. Dengan kata lain, bagaimana siswa dapat membuat kaitan antar konsep, sedangkan konsep itu sendiri belum dipahami dan dikuasai sepenuhnya.

Agar dapat mengaitkan hubungan antar konsep, siswa bukan hanya sekedar menghafal konsep-konsep elastisitas, akan tetapi siswa harus memiliki pemahaman dan penguasaan yang mendalam terhadap konsep tersebut. Jika satu konsep sudah dipahami dan dikuasai dengan baik, maka akan memudahkan bagi siswa untuk membuat keterkaitan antara konsep tersebut.

Demikian halnya dengan kesulitan menguasai rumus. Dari hasil penelitian diperoleh siswa yang mengalami kesulitan menguasai rumus adalah $71,3 \%$, sedangkan sisanya $(28,7 \%)$ siswa yang tidak mengalami kesulitan menguasai rumus. Kesulitan menguasai rumus disebabkan karena siswa tidak memahami penggunaan simbol, penggunaan tanda-tanda operasional matematika, dan penggunaan satuan. Diketahui bahwa mata pelajaran fisika adalah mata pelajaran yang menggunakan simbol, satuan, dan formula. Formula yang digunakan diperoleh dan dijabarkan dengan menggunakan perhitungan matematis.

Wijaya dkk (2012) menyatakan bahwa fe-nomena alam dalam fisika sering digambarkan dan dijelaskan oleh simbol dan formula matematika. Oleh karena itu, penguasaan konsep fisika juga membutuhkan adanya penguasaan terhadap konsep-konsep dasar matematika. Meltzer (2002) menyatakan bahwa ada korelasi positif antara penguasaan matematika dan keberhasilan dalam pencapaian hasil belajar fisika, sedangkan Rusilowati (2006) melaporkan bahwa salah satu penyebab kesulitan belajar fisika siswa adalah karena lemahnya kemampuan matematis. Dengan rendahnya kemampuan matematis siswa, maka siswa akan semakin tidak memiliki kemampuan untuk menjabarkan rumus-rumus yang dipelajari.

Untuk dapat menguasai rumus, siswa harus mengetahui arti dan simbol serta satuan dari suatu

Tabel 2. Presentase Kesulitan Belajar Siswa pada Materi Elastisitas Bahan sesudah Menggunakan Strategi Pembelajaran Inkuiri

\begin{tabular}{lccc}
\hline \multicolumn{1}{c}{ Jenis Kesulitan Belajar } & Tidak & Cukup & \multirow{2}{*}{ Sulit } \\
\hline 1. Kesulitan dalam memahami materi & Sulit & Sulit & 90,8\% \\
2. Kesulitan dalam mengaitkan hubungan antar konsep & $89,2 \%$ & $6,7 \%$ & $2,5 \%$ \\
3. Kesulitan dalam mengerti rumus & $87,1 \%$ & $8,8 \%$ & $4,1 \%$ \\
4. Kesulitan mengoperasikan rumus dalam menyelesaikan soal & $91,3 \%$ & $5,6 \%$ & $3,1 \%$ \\
\hline
\end{tabular}

Tabel 3. Kualifikasi dan Persentase Siswa dalam Skor Pencapaian Nilai Akhir

\begin{tabular}{cccc}
\hline Tingkat penguasaan & Frekuensi & Presentase & Kualifikasi \\
\hline $86-100$ & 18 & 46,1 & Sangat baik \\
$76-85$ & 19 & 48,8 & Baik \\
$66-75$ & - & - & Cukup \\
$<66$ & 2 & 5,1 & Gagal \\
\hline \multirow{2}{*}{ Rata - rata skor pencapaian $=\frac{\sum \text { skor pencapaian }}{\sum \text { siswa }}=\frac{3310,58}{39}=84,9$} \\
\hline
\end{tabular}


rumus agar dapat menghubungkan keterkaitan antar satu rumus dengan rumus yang lain. Jika kemampuan ini tidak dimiliki oleh siswa, maka siswa akan sulit dalam menguasai rumus yang digunakan. Dengan adanya ketidakmampuan menguasai rumus, maka tentu saja siswa akan semakin sulit untuk menerapkan rumus tersebut dalam penyelesaian soal. Dalam artian bahwa jika siswa tidak mengerti dan menguasai rumus, maka siswa tidak akan dapat memahami bagaimana, dan rumus apa yang tepat digunakan untuk menyelesaikan suatu pertanyaan. Dari hasil penelitian diperoleh siswa yang mengalami kesulitan dalam mengoperasikan rumus saat menyelesaikan soal sebanyak $79 \%$. Kesulitan yang dialami berupa ketidakmampuan siswa dalam mengkonversi satuan, merubah rumus sesuai variabel yang ditanyakan, atau salah menggunakan rumus dikarenakan siswa belum bisa menganalisis soal-soal tersebut.

Secara keseluruhan kesulitan siswa dalam mempelajari konsep elastisitas bahan yang meliputi penguasaan konsep, mengaitkan antar konsep, menguasai rumus atau formula, dan menerapkan formula dalam penyelesaian soal menunjukkan persentase yang tinggi, dibandingkan dengan siswa yang tidak mengalami kesulitan dalam mempelajari konsep elstisitas bahan tersebut. Jika dianalisis secara komprehensif dari setiap kesulitan belajar yang dihadapi oleh siswa khususnya pada konsep elastisitas bahan, pada dasarnya kesulitan siswa dalam mempelajari konsep elastisitas bahan merupakan suatu akumulasi. Artinya bahwa, jika pada awalnya siswa tidak menguasai konsep, maka siswa akan kesulitan mengaitkan konsep tersebut. Dengan adanya kesulitan mengaitkan konsep, siswa tidak memahami dan akan semakin sulit memahami formula-formula yang digunakan dan dijabarkan dalam konsep tersebut. Pada akhirnya dengan tidak menguasai konsep, tidak menguasai rumus atau formula, maka siswa tidak akan mampu dan akan semakin sulit dalam menerapkan formula yang sesuai untuk menyelesaikan suatu pertanyaan fisika, khususnya pada konsep elsatisitas bahan.

Kesukaran-kesukaran siswa dalam menyelesaikan soal-soal ini mengindikasikan bahwa siswa mengalami kesulitan belajar pada konsep elastisitas bahan. Dengan demikian, kesulitan ini perlu diatasi dalam proses pembelajaran dan salah satu alternatif dalam mengatasi kesulitan belajar siswa ini adalah dengan menggunakan pembe- lajaran inkuiri. Simatupang dan Tiarmida (2015 pembelajaran inkuiri adalah model pembelajaran yang membawa siswa secara langsung kedalam proses ilmiah. Inkuiri tidak hanya mengembangkan kemampuan intelektual tetapi seluruh potensi yang ada termasuk pengembangan emosional dan pengembangan keterampilan.

\section{Analisis Kesulitan Belajar Siswa setelah Peng- gunaan Strategi Pembelajaran Inkuiri}

Berdasarkan hasil penelitian dapat diketahui bahwa setelah penggunaan strategi inkuiri dalam pembelajaran fisika pada konsep elastisitas bahan, kesulitan siswa dalam menguasi konsep mengalami penurunan. Sebelum penggunaan inkuiri, sebanyak $69,2 \%$ siswa mengalami kesulitan menguasai konsep, sedangkan setelah penggunaan strategi inkuiri, hanya $2,5 \%$ siswa yang mengalami kesulitan. Pada kemampuan mengaitkan antar konsep sebelum penggunaan inkuiri, sebanyak $82,5 \%$ siswa mengalami kesulitan, akan tetapi setelah penggunaan inkuiri, hanya $4,1 \%$ siswa yang masih menunjukkan kesulitan dalam belajar.

Kemampuan menguasai rumus juga mengalami penurunan dari $71,3 \%$ siswa yang sulit menguasai rumus sebelum menggunakan strategi inkuiri. Setelah penggunaan strategi inkuiri, hanya $4,1 \%$ siswa yang masih mengalami kesulitan. Demikian halnya dengan kemampuan mengoperasikan rumus untuk menyelesaikan soal atau pertanyaan,sebelum penggunaan inkuiri sebanyak $79 \%$ siswa yang mengalami kesulitan, namun setelah penggunaan inkuiri, hanya 3,1\% siswa yang mengalami kesulitan.

Hasil ini menunjukkan bahwa setelah penggunaan strategi inkuiri sebanyak 97,5\% siswa sudah menguasai konsep elastisitas bahan, 95,9\% siswa sudah mampu mengaitkan antar konsep, 95,9\% siswa sudah menguasai rumus, dan 91,3\% siswa sudah mampu mengoperasikan rumus untuk menyelesaikan pertanyaan fisika khususnya pada konsep elastisitas bahan.

Hasil ini memberikan gambaran kemampuan strategi inkuiri dalam membantu siswa menguasai konsep elastisitas bahan. Salah satu tahapan pembelajaran dalam strategi inkuiri adalah adanya kemampuan siswa merumuskan masalah. Ketika siswa diajarkan untuk merumuskan masalah, maka siswa harus mendalami konsep yang dipelajari, sehingga siswa dapat menemukan masalah apa yang terdapat dari konsep ter- 
sebut. Jika siswa sudah memiliki penguasaan yang mendalam terhadap konsep tersebut, maka kemampuan-kemampuan lain akan muncul dari diri siswa. Rizal (2014) menyatakan bahwa pembelajaran inkuiri dapat membantu meningkatkan keterampilan proses dan penguasaan konsep siswa.

Strategi pembelajaran inkuiri juga membantu siswa membuat keterkaitan antara konsepkonsep tersebut, dimana pada salah satu tahapan strategi pembelajaran inkuiri, yaitu; merumuskan masalah, siswa dituntut untuk menetapkan mana konsep/prinsip yang tergolong variabel kontrol, mana konsep/prinsip yang tergolong variabel manipulasi dan mana konsep/prinsip yang tergolong variabel respon. Kemampuan mengaitkan antar konsep sebenarnya tekait dengan kemampuan sebelumnya yaitu kemampuan menguasai konsep. Hal ini dapat saja dipahami, bahwa jika siswa sudah menguasai konsep-konsep yang dipelajari, maka siswa akan mudah membuat kaitan antar konsep-konsep tersebut. Gormally et al (2009) menyatakan bahwa strategi inkuiri mampu meningkatkan kemampuan literasi sains, dan kemampuan saintifik siswa. Dengan kemampuan literasi sains, maka siswa akan mampu membuat generalisasi dari konsep-konsep yang dipelajari yang pad akhirnya akan menimbulkan pengalaman belajar baru yang lebih tertanam dalam diri siswa.

Sejalan dengan kemampuan mengaitkan antar konsep, maka siswa juga menunjukkan kemampuan menguasai rumus, yang diikuti oleh peningkatan dalam kemampuan menerapkan rumus yang sudah dikuasai untuk menyelesaikan pertanyaan yang diberikan.

Hasil ini berarti startegi pembelajaran inkuiri membantu siswa mengerti arti, dan simbolsimbol serta satuan dari suatu rumus, sehingga mampu menerapkannya dalam menyelesaikan soal, dan ini merupakan keterampilan siswa untuk memecahkan masalah (problem solving). Hasil ini sesuai dengan yang dilaporkan oleh Rust (2011) bahwa pembelajaran fisika dengan strategi inkuiri berhasil meningkatkan keterampilan memecahkan masalah, dan pemahaman konseptual siswa.

Dalam proses pembelajaran dengan menggunakan strategi pembelajaran inkuiri pada tahapan pengumpulan data siswa diberi Lembar Kerja Ssiswa yang merupakan lembar kegiatan siswa selama proses pembelajaran. Dalam LKS tersebut terdapat soal-soal untuk mengecek pemahaman siswa mengenai materi elastisitas bahan, yang di dalamnya juga terdapat pertanyaan yan bertujuan mengetahui kemampuan siswa menguasai dan menggunakan rumus.

Strategi pembelajaran inkuiri juga dapat mengatasi kesulitan dalam mengoperasikan rumus saat menyelesaikan soal, yakni kesulitan dalam mengkonversi satuan dan merubah rumus sesuai variabel yang ditanyakan. Pada saat mengoperasikan rumus untuk menyelesaikan soal siswa harus mempunyai 4 kategori kemampuan kognitif sekaligus, yaitu kemampuan $\mathrm{C}_{3}$ (aplikasi rumus), kemampuan $\mathrm{C}_{4}$ (analisis rumus yang digunakan), Kemampuan $\mathrm{C}_{5}$ (sintesis), dan kemampuan $\mathrm{C}_{6}$ (evaluasi), sehingga sering kali siswa mengalami kesulitan dalam mengoperasikan rumus saat menyelesaikan soal (Wijayanti dkk, 2010). Namun, dengan menggunakan strategi pembelajaran inkuiri, kesulitan mengoperasikan rumus saat menyelasaikan soal dapat teratasi.

Secara keseluruhan, setelah penggunaan strategi inkuiri, kesulitan-kesulitan belajar siswa pada konsep elastisitas bahan, mengalami penurunan, sedangkan kemampuan menguasai konsep, mengaitkan antar konsep, menguasai rumus, dan kemampuan mengoperasikan rumus untuk menyelesaikan soal fisika mengalami peningkatan. Dengan demikian, dapat dikatakan pembelajaran inkuiri dapat mengatasi kesulitan belajar, yakni memahami materi, mengaitkan hubungan antar konsep, mengerti rumus, dan mengoperasikan rumus saat menyelesaikan soal. Hal ini dilihat dari presentase hasil angket kesulitan belajar pada materi elastisitas bahan sebelum dan sesudah dengan menggunakan strategi pembelajaran inkuiri. Pembelajaran inkuiri, dapat membimbing siswa menemukan konsep secara mandiri, melalui kegiatan percobaan.

\section{Hasil Belajar yang Diperoleh Siswa}

Hasil penelitian menunjukkan keberhasilan siswa yang terlihat pada nilai akhir siswa selama kegiatan belajar mengajar berlangsung dengan menggunakan strategi pembelajaran inkuiri. Secara individual dan klasikal 95\% siswa telah memperoleh hasil melampaui kriteria ketuntasan minimal yang dipersyaratkan, walaupun dengan kualifikasi yang berbeda-beda. Sisanya, dua siswa belum berhasil mencapai kriteria ketuntasan minimal. Secara keseluruhan dapat dilihat rata-rata skor pencapaian nilai akhir siswa, yaitu 84,9.

Hasil ini menunjukkan bahwa penggunaan strategi inkuiri mampu meningkatkan hasil belajar 
siswa. Inkuiri juga merupakan salah satu cara meingkatkan keterampilan proses sains. Dalam keterampilan proses sains, semua kemampuan siswa (kognitif, afektif, dan psikomotor) berkembang dengan baik. Dalam perkembangan inilah masingmasing ranah ini memberi konstribusi yang nyata dalam pembentukan hasil belajar siswa, karena masing-masing ranah tercapai dalam kualifikasi baik sampai sangat baik, maka akan memberi konstribusi yang baik pula pada nilai akhir. Subali (2011) menyataka bahwa peserta didik yang gagal dalam prestasi menunjukkan bahwa peserta didik tidak disiapkan dengan baik untuk memahami cakupan atau ruang lingkup ateri yang diujikan). Keterampilan proses sains yang terintegrasi dalam pembelajaran inkuiri dapat mempersiapkan siswa untuk menghadapi ujian atau tes yang lebih baik, sehingga memberikan hasil sesuai yang diharapkan.

Mushtag dan Khan (2012) mengemukakan bahwa terdapat faktor-faktor yang perlu dipertimbangkan dalam penentuan nilai akhir, antara lain faktor pencapaian atau prestasi, faktor usaha, faktor aspek pribadi dan sosial, dan faktor kebiasaan kerja. Keempat faktor yang telah disebutkan di atas perlu dipertimbangkan, sehingga penilaian akhir yang dilakukan itu dapat lebih mendekati pada prinsip kebulatan atau prinsip keutuhan serta merupakan nilai akhir yang dapat menggambarkan secara bulat, utuh dan lengkap mengenai diri peserta didik, baik dari segi kecerdasan intelektual, sikap mental maupun kepribadiannya, sehingga untuk penentuan nilai akhir dipengaruhi dari nilai kognitif (LKS), serta nilai afektif dan psikomotorik yang dilihat dari lembar observasi dan nilai formatif.

Berdasarkan hasil penelitian secara keseluruhan, dapat dikatakan bahwa strategi inkuiri dapat memperbaiki kualitas belajar siswa yakni mampu mengatasi kesulitan siswa dalam belajar fisika, dan juga mampu meningkatkan hasil belajar fisika siswa khususnya pada konsep elastisitas bahan. Hasil ini sejalan dengan yang dinyatakan oleh Hussain dkk (2011) bahwa pembelajaran inkuiri memberikan pengaruh signifikan terhadap hasil belajar siswa jika dibandingkan dengan pembelajaran konvensional. Dengan demikian, dapat dikatakan bahwa penggunaan strategi pembelajaran inkuiri dapat membantu siswa dalam mengatasi kesulitan belajar dan mencapai hasil belajar siswa pada konsep elastisitas bahan.

\section{SIMPULAN}

Berdasarkan hasil penelitian dan pembahasannya, maka penulis dapat menyimpulkan bahwapPenggunaan staretgi pembelajaran inkuri dapat membantu mengatasi kesulitan-kesulitan belajar, yakni kesulitan dalam memahami materi, kesulitan dalam mengaitkan hubungan antar konsep, kesulitan dalam mengerti rumus, dan kesulitan dalam mengoperasikan rumus saat menyelesaikan soal. Penggunaan startegi pembelajaran inkuiri juga dapat membantu siswa kelas XI IPA4 SMA Negeri 5 Ambon dalam mencapai nilai akhir pada materi elastisitas bahan pada kualifikasi baik $(84,9)$.

\section{UCAPAN TERIMA KASIH}

Penelitian ini merupakan penelitian kolaborasi yang dibiayai oleh Fakultas Keguruan dan Ilmu Pendidikan Universitas Pattimura. Penulis mengucapkan terima kasih kepada Pimpinan Fakultas untuk pendanaan tersebut. Penulis juga mengucapkan terima kasih kepada Kepala SMA Negeri 5 Ambon atas kerja sama, sehingga menjamin terlaksananya penelitian ini.

\section{DAFTAR PUSTAKA}

Checkley, D. 2010. "High School Students' Perceptions of Physics, Faculty of Education". Lethbridge, Canada.

Derlina \& Afriani Nst, Lina. 2016. "Efek Penggunaan Model Pembelajaran Inquiry Training Berbantuan Media Visual dan Kreativitas terhadap Keterampilan Proses Sains Siswa". Cakrawala Pendidikan, Juni 2016 Tahun XXXV, No. 2. Pp: 153-163.

Elwan, A.A,. Serage, M., \& Alwan, A. 2013. "The institutional factors affecting the achievement in Physics in Tripoli". Libya. VFAST Transactions on Research in Education, 1(2), 1-18.

Gormally, C., Brickman, P., Hallar, B., \& Armstrong, N. 2009. "Effects of Inquiry-Based Learning on Students Science Literacy Skills and Confidence". International Journal For The Scholarship of Teaching And Learning, 3(2), 1-22.

Hamalik, O. 1990. Metode Belajar dan KesulitanKesulitan Belajar. Bandung: Tarsito. 
Hanafiah, Nanang., dan Suhana. 2009. Konsep Strategi Pembelajaran. Badung: Refika Aditama.

Hussain, A., Azeem, M., \& Shakoor, A. 2011. "Physics Teaching Methods: Scientific Inquiry vs Traditional Lecture". International Journal of humanities and Social Science, 1(19), 269-276.

Martini, J. 2014. Kesulitan Belajar Perspektif, Asesmen, dan Penanggulangannya. Jakarta; Ghalia Indonesia.

Meltzer, D.E. 2002. “The Relationship Between Mathematics Preparation and Conceptual Learning Gains in Physics: A Possible "Hidden Variable" in Diagnostic Pretest Scores". American Journal of Physics, 70(12), 1259- 1268

Mushtag, I. \& Nawaz Khan, S. 2012. "Factors Affecting Students's Performance". Global Journal of Management and Business Research, 12(9), 1-7.

Ngasarotur, L., Khotimah, R., \& Partono. 2015. "Pengaruh Model Pembelajaran Inkuiri Terbimbing terhadap Hasil Belajar Fisika Siswa Kelas VIII SMP Negeri 4 Metro Semester Genap Tahun Pelajaran 2013/2014". Jurnal Pendidikan Fisika, III(1), 64-72.

Rizal, M. 2014. "Pengaruh Pembelajaran Inkuiri Terbimbing dengan Multi Representasi terhadap Keterampilan Proses Sains dan Penguasaan Konsep IPA Siswa SMP". Jurnal Pendidikan Sains, 2(3), 159-165.

Rusilowati, A. 2006. "Profil Kesulitan Belajar Fisika Pokok Bahasan Kelistrikan Siswa SMA di Kota Semarang". Jurnal Pendidikan Fisika Indonesia, 4(2), 100-106.

Rust, P. M. H. 2011. "The Effects of Inquiry Instruction on Problem Solving and Conceptual Knowledge in Ninth Grade Physics Class". Montana State University, Bozeman, Montana.
Simatupang, S., \& Tiramaida. 2015. "Pengaruh Model Pembelajaran Inkuiri terhadap Hasil Belajar Siswa pada Materi Pokok Listrik Dinamis di Kelas X Semester II SMA Negeri 8 Medan Tahun Pelajaran 2013/2014”. Jurnal Ikatan Alumni Fisika Universitas Negeri Medan, 1(1), 31-41.

Subali, B. 2011. "Pengukuran Kreativitas Keterampilan Proses Sains dalam Konteks Assessment For Learning". Cakrawala Pendidikan, Februari 2011, Th. XXX, No.1, 130-144.

Sudjana, N. 1999. Metode Statistik. Bandung: Tarsito

Trianto. 2010. Mendesain Model Pembelajaran Inovatif-Progresif. Jakarta: Prenada Media Group.

Ukoh, E.E. 2012. "Effect of Interactive Invention Instructional Strategy on NCE Pre-Service Teacher's Achievement in Physics and Acquisition of Science Process Skills," Journal of Innovative Research in Management and Humanities, 3(1), 122-131.

Wijaya, M., Setiawan, A., \& Tjiang, C.P. 2012. "Descriptive Analysis of Mathematical Modeling Ability, Logical Inference Ability, and Academic Achievement in The Training of Vocational School Physics Teachers. Proceedings of the 2nd UPI International Conference on Technical and Vocational Education and TrainingBandung, Indonesia, 4-5 December 2012, Pp: 115-119.

Wijayanti., Mosik, N., \& Hindarto. 2010. "Explorasi Kesulitan Belajar Siswa pada Pokok Bahasan Cahaya dan Upaya Peningkatan Hasil Belajar melalui Pembelajaran Inkuiri Terbimbing". Jurnal Pendidikan Fisika Indonesia, 6 (2010), 1-5. 